УДК 346.24

DOI https://doi.org/10.32849/2663-5313/2019.12.24

\title{
Олена Черненко,
}

канд. юрид. наук, старший науковий співробітник

Науково-дослідного інституту приватного права і підприємничтва

імені академіка Ф. Г. Бурчака

Національної академії правових наук Украйни

\section{ПРАВОВИЙ РЕЖИМ МАЙНА ДЕРЖАВНИХ АКЦІОНЕРНИХ ТОВАРИСТВ}

У статті розглянуто проблемні питання, пов'язані з правовим режимом майна акиіонерних товариств, власником яких є держава. Питання майнових відносин в акиіонерному товаристві регулюються Господарським кодексом України, Цивільним кодексом України, Законом України «Про акиіонерні товариства» та иілою низкою підзаконних нормативно-правових актів. Аналіз наукових джерел та чинного законодавства дає підстави стверджувати, що свогодні відсутній єдиний підхід до розуміння правового режиму майна державних акиіонерних товариств.

У зв'язку з иим низка вчених вважає, що державне майно, яке передане до статутного капіталу державного акиіонерного товариства, залишається у державній власності, а відчуження його можливе тільки органами приватизачії через визначені законом приватизачійні процедури.

Найбільш обгрунтованою, на нашу думку, $\epsilon$ інша позиція, відповідно до якої акиіонерне товариство за своєю природою є об'єднанням капіталів $і$ вимагає закріплення за ним майна не на праві господарського відання або оперативного управління, а на праві власності. Саме тому будь-яке майно, передане державою як учасником державному акиіонерному товариству, включається до його статутного капіталу і стає власністю товариства. За державою зберігаються корпоративні права, а акиіонерна компанія набуває прав власника.

Правові режими майна акиіонерних товариств з участю $i$ без участі держави не повинні відрізнятись. Усі акціонерні товариства мають визнаватись власниками свого майна, а держава повинна впливати на управління товариством через механізм реалізації своїх корпоративних прав. До держави, яка набула право на акиії, переходять у сукупності всі права на иінні папери включно з правом на отримання частини прибутку акціонерного товариства у вигляді дивідендів та правом на отримання частини майна акціонерного товариства у разі його ліквідації, правом на управління акиіонерним товариством.

Враховуючи вищенаведене, необхідно на рівні закону врегулювати низку питань, пов'язаних 3 правовим режимом майна, яке було передане до статутного капіталу (фонду) акиіонерного товариства, власником якого є держава.

Ключові слова: господарське товариство, статутний капітал, державна власність, акції, корпоративні права.

Постановка проблеми. У радянські часи державна власність була домінуючою формою власності на засоби виробництва. Декларацією про державний суверенітет України, прийнятою Верховною Радою Української РСР 16.07.1990р., була проголошена самостійність Української держави і захист усіх форм власності. У процесі фундаментальних соціально-економічних та політико-правових перетворень, що зазнавала Україна на початку 90 -х років минулого століття, державна власність перестала бути єдиною організаційною формою господарювання, проте деякі питання, пов'язані з державною власністю, залишаються й досі дискусійними [1].

Дослідженню правового режиму майна державних акціонерних товариств присвячені праці таких вітчизняних вчених, як
Ю.М. Дзера, А.М. Захарченко, О.О. Кравчук, I.В. Лукач, I.А. Селіванова.

Метою наукової статті $€$ дослідження особливостей правового режиму майна, що було передане до статутного капіталу (фонду) акціонерного товариства, власником якого є держава.

Виклад основного матеріалу. Основу правового режиму майна суб'єктів господарювання, на якій базується їх господарська діяльність, відповідно до ч. 1 ст. 133 ГК України становить право власності, а також та інші речові права - право господарського відання, право оперативного управління.

А.В. Венедиктов під правовим режимом майна розумів обсяг прав та обов'язків окремих підприємств та органів управління 
стосовно майна, що закріплене за підприємством, а також порядок використання цього майна та звернення на нього стягнення за зобов'язаннями підприємства [2]. I.B. Єршова визначає правовий режим майна як сукупність встановлених законодавством правил з володіння, користування та розпорядження [3, с. 162].

Г.В. Пронська вважала, що поняття правового режиму майна підприємства охоплює встановлену правовими нормами структуру цього майна, порядок його набуття, використання і вибуття, а також звернення на нього стягнень кредиторів [4]. На думку В.С. Щербини, це визначення правового режиму є найбільш вдалим, адже воно дозволяє з'ясувати таке: по-перше, структуру (складові частини, види) майна, закріпленого за суб'єктом господарювання, що створює можливість визначити особливості правового режиму окремих видів зазначеного майна; по-друге, порядок (джерела, способи, процедуру) формування майнової бази та майнового стану (шляхом відображення його засобами бухгалтерського обліку) суб'єкта господарювання; по-третє, порядок використання (експлуатаціï) різних видів майна в процесі здійснення господарської діяльності (в тому числі його амортизації, застосування норм і нормативів тощо); по-четверте, порядок вибуття майна з майнової сфери суб'єкта господарювання (відповідно до умов укладених договорів, у тому числі у вигляді санкцій за порушення договірних зобов'язань, а також шляхом використання у своїй господарській діяльності та у вигляді сплати податків та інших обов'язкових платежів, а також шляхом вилучення майна за рішенням уповноважених органів, у тому числі у вигляді санкцій за порушення правил здійснення господарської діяльності тощо) [5].

Отже, на специфіку правового режиму майна суб'єкта господарювання безпосередньо впливають такі фактори: форма власності; правова підстава, на якій належить майно тому чи іншому суб'єкту господарювання; вид та організаційно-правова форма суб'єкта господарювання тощо. Тому вчені розкривають зміст та сутність правового режиму майна акціонерного товариства як встановлені у законодавстві правила реалізації правомочностей з володіння, користування та розпорядження майном товариства в процесі підприємницької діяльності [6, с. 8].

Питання майнових відносин в акціонерному товаристві регулюється ЦК України, ГК України та Законом України «Про акціонерні товариства» й низкою підзаконних нормативно-правових актів.
Одним із видів господарських організацій, які належать до державного сектора економіки, є державне акціонерне товариство. Слід зазначити, що поняття «державне акціонерне товариство» вживається у багатьох нормативно-правових актах (Господарському кодексі України, законах України «Про акціонерні товариства», «Про управління об'єктами державної власності», «Про приватизацію державного майна»), проте у згаданих актах відсутнє визначення цього поняття.

Нині існує два полярних підходи до визначення правового режиму майна державних акціонерних товариств, 100\% акцій яких перебувають у державній власності. Прихильники першого переконані, що акціонерні товариства, засновником і єдиним акціонером яких є держава в особі органів виконавчої влади, мають спеціальний правовий режим майна порівняно з іншими господарськими товариствами, які створюються у загальному порядку.

Так, Ю.М. Дзера вважає, що аналіз положень нормативно-правових актів, які стосуються приватизації державного майна, дає підстави зробити висновок, що зміна державної форми власності може відбуватися виключно шляхом приватизації. Державне майно, що передане державою до статутного фонду (капіталу) державного унітарного підприємства, корпоратизованого у акціонерне товариство, сто відсотків акцій якого залишається у власності держави, до моменту завершення процедури приватизації (продажу у приватну власність належних державі акцій такого акціонерного товариства) є державною власністю [7].

Тобто державне майно, передане до статутного капіталу (фонду) державного акціонерного товариства, залишається у державній власності, а відчуження його можливе тільки органами приватизації через визначені законом приватизаційні процедури. Згадана позиція була відображена у листі Міністерства юстиції України від 11.01.2007 р. №19-32/2 «Роз'яснення порядку реєстрації прав власності на об'єкти нерухомого майна залежно від форми власності» та знайшла своє практичне відображення у низці судових рішень.

Проте $є$ й інша позиція, яка полягає в тому, що будь-яке майно, передане державою як учасником державному акціонерному товариству, включається до його статутного капіталу (фонду) і стає власністю товариства.

Так, Л.В. Винар звертає увагу й на інші елементи правового статусу державного акціонерного товариства, визначаючи, що 
таким товариством є юридична особа приватного права, заснована державою в особі уповноваженого державного органу, яка має особливий порядок формування статутного капіталу (фонду), порядок управління та спеціальну правоздатність, у статутному капіталі (фонді) якої державі належить кількість акцій, що відповідно до законодавства забезпечує право вирішального впливу на прийняття рішень цим товариством $[8$, с. 6$]$.

Держава може створювати юридичні особи як публічного, так і приватного права (ст. 81 та ст. 167 ЦК України). Відповідно до Закону України «Про акціонерні товариства» публічні акціонерні товариства залишаються за типом публічними акціонерними товариствами, якщо їхні акції допущені до торгів на фондовій біржі. До решти публічних акціонерних товариств, в тому числі 100\% або частина акцій яких перебуває в державній власності, застосовуватимуться такі ж вимоги, як і до приватних акціонерних товариств.

Однією з відмінностей між юридичними особами публічного права та юридичними особами приватного права, засновником (учасником) яких $є$ держава в особі своїх органів, є те, що юридичні особи приватного права, на відміну від юридичних осіб публічного права, є власниками переданого їм державного майна, а держава $€$ лише власником акцій і володіє корпоративними правами таких юридичних осіб - господарських товариств. При цьому розмір частки, що належить державі, або ж кількість акцій, що є у державній власності, не свідчить про належність такого товариства до юридичної особи публічного права.

Остання правова позиція підтверджується і тим, що акціонерне товариство за своєю природою є об'єднанням капіталів, яке вимагає закріплення за ним майна не на праві господарського відання або оперативного управління, а на праві власності незалежно від кількості акцій, що належать державі.

Статутний капітал акціонерного товариства поділений на визначену кількість часток однакової номінальної вартості, корпоративні права за якими посвідчуються акціями (ч. 1 ст. 152 ЦК України).

На установчих зборах акціонерного товариства, що проводяться до моменту реєстрації акціонерного товариства, окрім затвердження результатів розміщення акцій, вирішується питання про затвердження оцінки майна, що вноситься засновниками в рахунок оплати акцій товариства (ст. 10 Закону України «Про акціонерні товариства»). Оплата вартості акцій, що розміщуються під час заснування акціонерного товариства, може здійснюватися грошовими коштами, цінними паперами (крім боргових емісійних цінних паперів, емітентом яких є засновник, та векселів), майном і майновими правами, нематеріальними активами, що мають грошову оцінку (ст. 10 Закону України «Про акціонерні товариства»).

У п. 53 Інформаційного листа Вищого господарського суду «Про деякі питання практики застосування норм Цивільного та Господарського кодексів України» від 07.04.2008 p. № 01-8/211 зазначено, що держава в особі її органів може бути не тільки засновником суб'єкта господарювання, а й його акціонером.

Крім того, у ч. 1 ст. 3 Закону України «Про управління об’єктами державної власності» серед об'єктів управління державної власності передбачені і корпоративні права, що належать державі, у статутних капіталах господарських організацій.

Внесення вкладу до статутного капіталу (фонду) товариства припиняє в держави право власності на нього. Таке майно переходить у власність створеної корпорації $[9$, c. 50]. Тобто при передачі державою в особі органу, уповноваженого управляти державним майном, майна як внеску до статутного капіталу (фонду) державного акціонерного товариства відбувається перехід права власності на зазначене майно від держави до державного акціонерного товариства.

До держави, яка набула право на акції, переходять у сукупності всі права за цінними паперами включно з правом на отримання частини прибутку акціонерного товариства у вигляді дивідендів та правом на отримання частини майна акціонерного товариства у разі його ліквідації, правом на управління акціонерним товариством, а також немайновими правами, передбаченими ЦК України та законом, що регулюе питання створення, діяльності та припинення акціонерних товариств.

Варто погодитись 3 тим, що правові режими майна акціонерних товариств з участю і без участі держави не повинні відрізнятись. Усі акціонерні товариства мають визнаватись власниками свого майна, а держава, як і всі інші акціонери, повинна впливати на управління товариством через механізм реалізації своїх корпоративних прав.

Не слід пов'язувати можливість набуття державними акціонерними товариствами права власності на передане їм державне майно виключно з проведенням його приватизації, оскільки приватизація не є єдиним способом відчуження державного майна. Так, законодавством передбачена можливість припинення права 
державної власності на певні об'єкти внаслідок іх передачі в комунальну власність, а також внаслідок безпосереднього продажу певних об'єктів державними підприємствами, установами, організаціями за попереднім погодженням 3 уповноваженими суб'єктами управління тощо.

Тому передача державного майна у власність акціонерному товариству може розглядатись як окремий спосіб відчуження такого майна (поряд із приватизацією й іншими). За державою повинні зберігатися корпоративні права, а акціонерна компанія повинна набувати прав власника [10, с. 44-48].

Так, наприклад, відповідно до п. 5.1 статуту Відкритого акціонерного товариства «ДАК «Автомобільні дороги України» його засновником та акціонером є держава в особі Державної служби автомобільних доріг України. Крім того, відповідно до п. 6.3 статуту Компанія є власником майна, переданого йому засновником до статутного фонду. Здійснюючи право власності, Компанія володіє, користується та розпоряджається належним їй майном, вчиняючи стосовно нього будь-які дії, що не суперечать закону та меті діяльності Компанії (п. 6.6).

У новій редакції статуту АТ «ДАК «Автомобільні дороги України» міститься аналогічне положення. Так, Компанія є власником: 1) майна, переданого засновником до ї̈ статутного капіталу у власність; 2) коштів, майнових і немайнових прав, цінних паперів, іншого рухомого і нерухомого майна; 3) продукції, виробленої Компанією у результаті господарської діяльності; 4) одержаних доходів; 5) капітальних вкладень; 6) грошових надходжень від дочірніх підприємств Компанії; 7) безоплатних чи благодійних внесків, пожертвувань від юридичних чи фізичних осіб; 8) майна, що передане дочірнім підприємствам на праві господарського відання; 9) іншого майна, набутого у власність на підставах, не заборонених законом, за час діяльності Компанії (п. 6.4. Статуту).

Здійснюючи право власності, Компанія володіє, користується та розпоряджається належним їй майном, вчиняючи стосовно нього будь-які дії, що не суперечать законодавству, цьому Статуту, іншим внутрішнім документам Компанії та меті iii діяльності. Відчуження (продаж, обмін, дарування тощо), передача в користування, у т.ч. в оренду, передача в заставу (іпотеку) основних засобів, списання з балансу майна Компанії та/або ї̈ дочірніх підприємств здійснюється в порядку, встановленому законодавством, цим Статутом та іншими внутрішніми документами Компанії (п. 6.6 Статуту).
Положення статуту АТ «ДАК «Автомобільні дороги України» підтверджують, що майно, яке передане засновником до статутного фонду Компанії, не є державним, воно належить товариству на праві власності, а товариство є суб'єктом права приватної власності (ст. 325 ЦК України).

При цьому необхідно звернути увагу на те, що до статутного капіталу державного акціонерного товариства можуть вноситись певні об'єкти державної власності для подальшого використання на обмежених речових правах [11, с. 138-139]. Так, на практиці трапляються випадки, коли окремі об'єкти державної власності, що передаються державним акціонерним товариствам на праві господарського відання або праві користування, позначаються як такі, що не включаються до статутного капіталу товариства (п. 27 Статуту ПАТ «НАК «Нафтогаз України»). Внаслідок цього вартість таких об'єктів державної власності при визначенні розміру статутного капіталу товариства не враховується, а їх передача товариству не вважається способом оплати одержаних державою акцій.

Отже, невпорядкованість правового режиму майна, переданого національним (державним) акціонерним компаніям, зумовила виникнення й низки проблем, пов'язаних із визначенням правового режиму їх майна. Нині при вирішенні питання правового режиму майна державних акціонерних товариств слід враховувати норми спеціальних законів, якщо такі є в наявності, та норми локальних актів, оскільки саме в них можуть бути закріплені положення щодо особливостей правового режиму майна державних акціонерних товариств, єдиним засновником та акціонером яких є держава.

\section{Висновки}

Враховуючи вищенаведене, можна дійти висновку, що є необхідність на рівні закону врегулювати питання стосовно правового режиму майна, яке було передане до статутного капіталу (фонду) акціонерного товариства, власником якого є держава.

\section{Список використаних джерел:}

1. Кравчук О.О. Державна власність як форма власності в Україні (аксіологічний аспект). URL: http://ela.kpi.ua/ bitstream/123456789/2916/1/19 pdf.

2. Венедиктов А.В. Государственная собственность. Ленинград : Издательство АН СССР, 1948. $388 \mathrm{c}$

3. Ершова И.В. Предпринимательское право : учебник, изд. 4 е, перераб. и доп. Москва : ИД «Юриспруденция», 2006. С. 162. 
4. Советское хозяйственное право : учебник / под общ. ред. докт. юрид. наук, проф. И.Г. Побирченко. К. : Высшая школа, 1985. С. 83

5. Щербина В.С. Поняття та зміст правового режиму майна суб'єктів господарювання. Юридична Украӥна. 2007. № 1. С. 71-79.

6. Елькин С.К. Правовой режим имущества акционерного общества : дисс. ... канд. юрид. наук : 12.00 .04 ; Рос. акад. наук, Ин т государства и права. Москва, 1998. С. 8

7. Дзера Ю. Особливості правового режиму майна, переданого державою до статутного фонду (капіталу) акціонерного товариства у результаті корпоратизації державного унітарного підприємства. Юридична Украӥна. 2010. № 4. С. 60-61.
8. ВинарЛ.В. Правовий статус юридичних осіб, заснованих державою : автореф. дис. ... канд. юрид. наук : 12.00 .03 «ивільне право і цивільний процес; сімейне право; міжнародне приватне право» ; Львів. нац. ун-т ім. І. Франка. Львів, 2006. 20 с.

9. Погрібний Д.І. Корпоративні права держави: поняття, підстави виникнення, механізм реалізації. Харків : ФІНН, 2009. С. 50.

10. Селіванова I.А. Проблеми правового статусу акціонерних товариств, в яких держава є акціонером. Вісник Верховного Суду Украйни. 2009 № 9 (109). C. 44-48.

11. Захарченко А.М. Управління об’єктами державної власності (господарсько-правовий аспекти) ; Донец. нац. ун-т ім. Василя Стуса. 2009. С. 138-139.

The article deals with the problematic issues related to the legal regime of state-owned joint-stock companies. Issues of property relations in a joint-stock company are governed by the Economic Code of Ukraine, the Civil Code of Ukraine, the Law of Ukraine "On Joint-Stock Companies" and a number of by-lawes. The analysis of scientific sources and current legislation gives grounds to claim that there is no single approach to understanding the legal regime of state joint-stock companies today.

In this regard, a number of scholars believe that state property that is transferred to the authorized capital of a state joint-stock company remains state-owned and can only be alienated by privatization bodies through privatization procedures defined by law.

The most reasonable, in our opinion, is a different position according to which a joint-stock company is by its nature a merger of capital and requires the attachment of property to it not on the right of economic management or on the right of operational management, but on the right of ownership. Therefore, any property transferred by the state as a participant to the state joint stock company is included in its authorized capital and becomes the property of the company. The state retains corporate rights and the joint stock company acquires the rights of the owner.

The legal regimes of property of joint-stock companies with and without the participation of the state should be no different. All joint-stock companies should be recognized as owners of their property, and the state should influence the management of the company through the mechanism of realization of their corporate rights. The State that has acquired the right to the shares will in the aggregate all the rights over the securities, including the right to receive part of the profit of the joint-stock company in the form of dividends and the right to receive part of the property of the joint-stock company in the event of its liquidation, the right to manage the joint-stock company.

In view of the above, it is necessary to regulate at law level a number of issues related to the legal regime of property that has been transferred to the authorized capital (fund) of a state-owned company.

Key words: state-owned joint-stock company, authorized capital, legal regime of property, corporate rights. 